\title{
Lounaslautanen julkisessa ruokapalvelussa - tarjonta ja toiveet
}

\author{
Sirpa Kurppa ${ }^{1}$, Merja Saarinen ${ }^{1}$, Mirja Viinisalo ${ }^{2}$, Helmi Risku-Norja ${ }^{3}$ \\ ${ }^{1}$ MTT Biotekniikka- ja elintarviketutkimus 31600 Jokioinen, etunimi.sukunimi@mtt.fi \\ ${ }^{2}$ Kuluttajatutkimuskeskus, Kaikukatu 3, PL 500531 Helsinki etunimi.sukunimi@ncrc.fi \\ ${ }^{3}$ MTT Biotekniikka- ja elintarviketutkimus 31600 Jokioinen, etunimi.sukunimi@mtt.fi
}

\section{Tiivistelmä}

Esitelmä perustuu Ympäristöklusteriohjelman hankkeen ” ConsEnv Kotitalouksien kulutusvalintojen ympäristövaikutukset ja niistä viestiminen ” tuloksiin. Hanke päättyi kesäkuun lopussa, esiteltiin loppuseminaarissa syyskuussa 2009 ja loppuraportoidaan vuoden 2010 alkupuoliskolla. Hankkeessa on tuotettu ympäristövaikutusarvio noin 35 erilaisesta lounaslautasesta eläinpainotteisista annoksista vegaaniannoksiin. Lounaat jakaantuivat kotona valmistettuihin, valmisruokalounaisiin ja koululounaisiin. Tässä esityksessä keskitytään julkisten ruokapalvelujen koululounaisiin, joista edellä mainitussa tutkimuksessa oli esimerkkinä yhden yläkoulun 9 erilaista lounasvaihtoehtoa.

Lounasannoksissa on noudatettu kouluille annettuja tasapainoisen lounaan suosituksia: 740 kcal/yläkouluikäisen nuoren lounas; energiasta 10-20 \% tulisi olla peräisin proteiineista, 25-25 \% rasvoista, 50-60 \% hiilihydraateista. Lounasnimikevaihtoehtoja verrattiin niiden todellisen kulutuksen mukaisesti koko koulun tasolla, jolloin esimerkiksi energian saanti vaihtelee, sen mukaan millainen menekki kullakin lounasannosnimikkeellä on. Tarkastelussa on korostettu erilaisten tuotantotapojen merkitystä lounaskoosteen ympäristövaikutuksissa. Myös kotimaisia ja ulkomaisia tuotteita on verrattu keskenään. Koululounaat osoittautuivat ilmastovaikutustensa ja rehevöittävyysvaikutustensa osalta asettuvan ruoka-annosten keskimääräiselle tai hieman kevyemmälle tasolle. Esimerkkikoulun peruslounaiden ilmastovaikutus oli lounasnimikkeestä riippuen väillä 0,56 kg ja 1,94 kg CO 2 ekv. / annos, ja rehevöittävyysmittarin arvot vaihtelivat välillä $0,5 \mathrm{~g}$ ja 2,5 g $\mathrm{PO}_{2}$ ekv / annos. Alustavien tulosten mukaan näyttää hyvin ilmeiseltä, että vuodenaikaisia sesonkeja noudatteleva ruokavalio muodostuisi ympäristön kannalta edullisimmaksi. Kuluttajien toiveet ovat kuitenkin erkaantumassa aidosta luonnonedellytyksiin linkittyvästä sesonkisuudesta. Varhaistuotteita odotetaan vuosi vuodelta aikaisemmin ja tiettyjä aikaisempia sesonkituotteita ympäri vuoden. Julkisissa ruokapalveluissa tuoreus on tärkeä kriteeri, mutta se ei linkity kotimaisten tai etenkään oman makkunnan tuotteiden ylivoimaisena hyödyntämisenä. Suomalaiselle ja monelle muullekin ruokakulttuurille perinnäinen luonnonolosuhteista ja resursseista riippuvuus ei enää realisoidu. Ympäristön kannalta suomalaisen raaka-ainetuotannon tulisi vahvistaa suomalaisen urbaanin väestön ymmärrystä ruokaraaka-ainetuotannon luonnonresurssiriippuvuudesta eikä pyrkiä kumoamaan sitä. Yhtenä mahdollisuutena julkisissa ruokapalveluissa on tarkemman raaka-ainepohjan osalta sesonkisuuntautuneen vuosittaisen ruokavalion suunnittelu. Tässä kohden tulisi nimenomaan muistaa, että ehdottomasti suurin osa ruoan ympäristövaikutuksista syntyy raakaainetuotannossa.

\section{Asiasanat:}

ruoka, LCA, ilmastovaikutus, rehevöittävä vaikutus, hiilidioksidiekvivalentti, fosfaattiekvivalentti, sesonkisuus, lautasmalli, julkinen ruokapalvelu, tuontiruoka 


\section{Johdanto}

Tämän tutkimuksen tavoitteena oli mitata kouluruokien ympäristövaikutukset ja tuottaa materiaalia, jota koulujen opettajat, ruokahuollosta vastaavat ja oppilaat voisivat käyttää ruoan ympäristövaikutusten merkityksen ymmärtämiseen ja kukin ryhmä omista lähtökohdistaan vaikutusten vähentämiseen.

\section{Aineisto ja menetelmät}

Kouluaterioita tarkasteltiin mahdollisimman todellisesta ja ajankohtaisesta näkökulmasta. Kohteeksi valittiin tuttuja ja suosittuja kouluruokia, joiden tiedetään olevan myös kotona tehtyinä tavanomaisia lapsiperheiden ruokia. Päivittäisestä ruokailusta esimerkkinä on lounas, jonka tulisi kattaa noin kolmannes päivittäisestä ravinnon tarpeesta. Koululounaat ovat suunnitteluperiodilla ravitsemuksellisesti täysipainoisia ja periaatteessa noudattavat lautasmallia, jossa puolet lautasesta täytetään vihanneksilla, neljännes hiilihydraattilähteellä ja neljännes proteiinilähteellä. Tosin oppilaat koostavat ruoka-annoksensa itse, jolloin aterioiden sisällöt voivat poiketa hyvin huomattavasti henkilöltä toiselle. Tässä esimerkissä kouluruokavaihtoehtoja verrattiin niiden todellisen kulutuksen mukaisesti koko koulun tasolla, jolloin esimerkiksi energian saanti vaihtelee lounasannosnimikkeittäin sen mukaan millainen menekki kullakin lounasannosnimikkeellä oli (Taulukko 1).

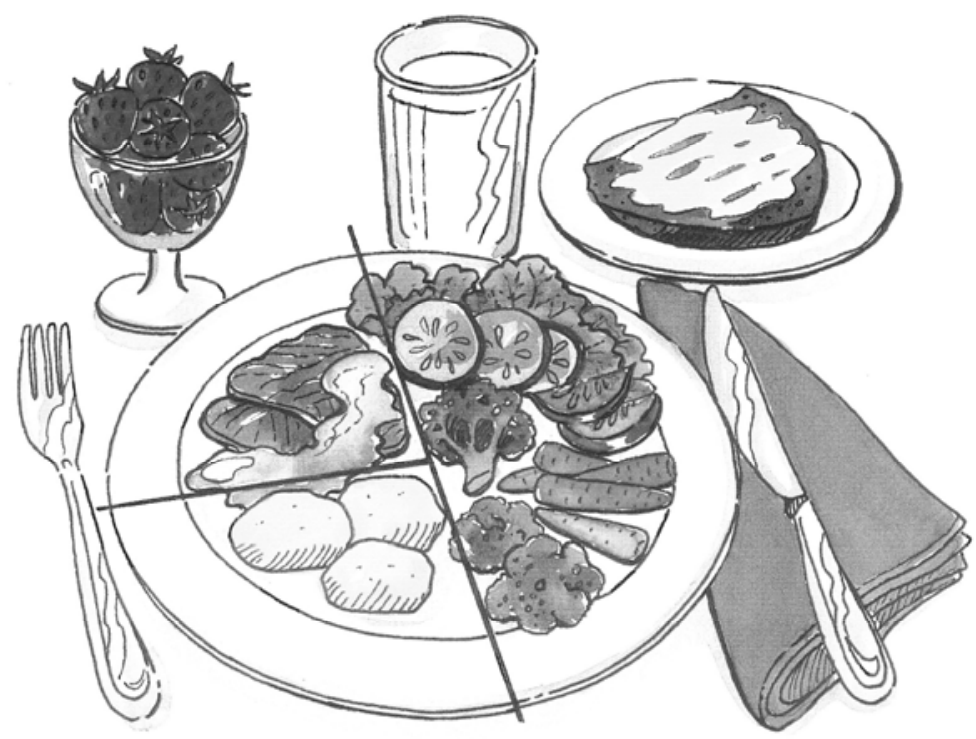

Lähde: Valtion ravitsemusneuvottelukunta

Kuva 1. Valtion ravitsemusneuvottelukunnan suosittelema lautasmalli.

Ravitsemussuositukset ovat: $740 \mathrm{kcal} / \mathrm{yläkouluikäisen} \mathrm{nuoren} \mathrm{lounas.} \mathrm{Energiasta} \mathrm{10-20} \mathrm{\%} \mathrm{tulisi}$ olla peräisin proteiineista, 25-25 \% rasvoista, 50-60 \% hiilihydraateista. Kuten yllä korostettiin, yksilötasolla ravitsemussuositukset eivät kaikkien oppilaiden kohdalla toteudu.

Lounasesimerkeillä pyrittiin myös hakemaan erilaisia vastakohtaisuuksia ja korostamaan myös eri tavalla tuotettujen tuotteiden vaikutusta lounaskoosteen ympäristövaikutukseen. Lisäksi kotimaisuustuontituote-kysymystä tarkasteltiin erikseen.

Koulujen ruokapalveluita ja ruokatarjontaa on arvioitu myös kuntien paikallisten ruokapalvelupäälliköiden vastausten perusteella. Tämä on toteutettu ruokahuoltoon liittyvässä MTT:n selvityksessä "Kestävät julkiset ruokapalvelut kuntien toiminnoissa”, toteuttajana Helmi Risku-Norja. Tämä aineisto julkaistaan kokonaisuudessaan erillisenä raporttina (Risku-Norja et al. 2010). 
Taulukko1. Kouluaterioiden reseptit ja ravitsemuksellinen laatu.

\begin{tabular}{|c|c|c|c|c|c|c|}
\hline & Annos & $\mathbf{k J}$ & kcal & hh & rasva & prot. \\
\hline Kirjolohikiusaus & 220 & 1188 & 282 & 23,5 & 15,4 & 12,0 \\
\hline Punajuurikuutiot & 50 & 140 & 34 & 7,0 & 0,3 & 0,6 \\
\hline Sekaleipä, vaalea, vehnäjauho, vehnärouhe & 70 & 761 & 182 & 32,4 & 2,9 & 5,9 \\
\hline Kasvirasvalevite, 60 \% rasvaa & 8 & 187 & 45 & 0,0 & 5,0 & 0,0 \\
\hline Rasvaton maito & 200 & 284 & 68 & 9,8 & 0,2 & 6,2 \\
\hline \multirow[t]{2}{*}{ Yhteensä } & & 2560 & 610 & 72,6 & 23,8 & 24,7 \\
\hline & & & & 290,5 & 214,5 & 98,9 \\
\hline \multicolumn{3}{|c|}{ Energian saanti \% hiilihydraateista, rasvasta, proteiinista } & & 47,6 & 35,1 & 16,2 \\
\hline Juureskiusaus & 220 & 990 & 236 & 20,5 & 14,4 & 5,9 \\
\hline Kiinankaali-kurkkusalaatti & 40 & 28 & 7 & 0,9 & 0,1 & 0,6 \\
\hline Salaattikastike & 5 & 86 & 21 & 0,7 & 2,0 & 0,0 \\
\hline Sekaleipä, vaalea, vehnäjauho, vehnärouhe & 70 & 761 & 182 & 32,4 & 2,9 & 5,9 \\
\hline Kasvirasvalevite, 60 \% rasvaa & 8 & 187 & 45 & 0,0 & 5,0 & 0,0 \\
\hline Rasvaton maito & 200 & 284 & 68 & 9,8 & 0,2 & 6,2 \\
\hline \multirow[t]{2}{*}{ Yhteensä } & & 2335 & 558 & 64,2 & 24,7 & 18,6 \\
\hline & & & & 256,78 & 222,06 & 74,53 \\
\hline \multicolumn{3}{|c|}{ Energian saanti \% hiilihydraateista, rasvasta, proteiinista } & & 46,1 & 39,8 & 13,4 \\
\hline Kinkkukiusaus & 220 & 1127 & 270 & 27,7 & 13,3 & 9,1 \\
\hline Kiinankaali-kurkkusalaatti & 40 & 28 & 7 & 0,9 & 0,1 & 0,6 \\
\hline Salaattikastike & 5 & 86 & 21 & 0,7 & 2,0 & 0,0 \\
\hline Sekaleipä, vaalea, vehnäjauho, vehnärouhe & 70 & 761 & 182 & 32,4 & 2,9 & 5,9 \\
\hline Kasvirasvalevite, 60 \% rasvaa & 8 & 187 & 45 & 0,0 & 5,0 & 0,0 \\
\hline Rasvaton maito & 200 & 284 & 68 & 9,8 & 0,2 & 6,2 \\
\hline \multirow[t]{2}{*}{ Yhteensä } & & 2472 & 592 & 71,4 & 23,6 & 21,8 \\
\hline & & & & 285,5 & 212,7 & 87,2 \\
\hline \multicolumn{3}{|c|}{ Energian saanti \% hiilihydraateista, rasvasta, proteiinista } & & 48,3 & 36,0 & 14,7 \\
\hline Lihamakaronilaatikko & 250 & 1632 & 383 & 33,4 & 17,4 & 25,0 \\
\hline Porkkanaraaste & 50 & 56 & 14 & 2,8 & 0,1 & 0,3 \\
\hline Rasvaton maito & 200 & 284 & 68 & 9,8 & 0,2 & 6,2 \\
\hline Salaattikastike & 5 & 86 & 21 & 0,7 & 2,0 & 0,0 \\
\hline Sekaleipä, vaalea, vehnäjauho, vehnärouhe & 70 & 761 & 182 & 32,4 & 2,9 & 5,9 \\
\hline kasvirasvalevite, 60 \% rasvaa & 8 & 187 & 45 & 0,0 & 5,0 & 0,0 \\
\hline \multirow[t]{2}{*}{ Yhteensä } & & 3005 & 712 & 79,1 & 27,7 & 37,5 \\
\hline & & & & 316,3 & 249,6 & 149,9 \\
\hline \multicolumn{3}{|c|}{ Energian saanti \% hiilihydraateista, rasvasta, proteiinista } & & 44,4 & 35,1 & 21,1 \\
\hline Kasvismakaroni & 250 & 1814 & 429 & 57,9 & 1,6 & 46,5 \\
\hline Porkkanaraaste & 50 & 56 & 14 & 2,8 & 0,1 & 0,3 \\
\hline Salaattikastike & 10 & 172 & 41 & 1,3 & 4,0 & 0,0 \\
\hline Sekaleipä, vaalea, vehnäjauho, vehnärouhe & 70 & 761 & 182 & 32,4 & 2,9 & 5,9 \\
\hline Kasvirasvalevite, 60 \% rasvaa & 10 & 223 & 53 & 0,0 & 6,0 & 0,0 \\
\hline \multicolumn{7}{|l|}{ vesi } \\
\hline & & 3025 & 719 & 94,4 & 14,7 & 52,8 \\
\hline & & & & 377,6 & 132,1 & 211,1 \\
\hline \multicolumn{3}{|c|}{ Energian saanti \% hiilihydraateista, rasvasta, proteiinista } & & 52,5 & 18,4 & 29,4 \\
\hline
\end{tabular}




\begin{tabular}{|c|c|c|c|c|c|c|}
\hline & Annos & $\mathbf{k J}$ & kcal & hh & rasva & prot. \\
\hline Punajuuripihvi & 120 & 476 & 114 & 8,8 & 6,2 & 5,3 \\
\hline Perunamuusi & 200 & 737 & 176 & 26,7 & 5,9 & 3,1 \\
\hline Kurkku-jäävuorisalaatti & 40 & 18 & 4 & 0,5 & 0,1 & 0,4 \\
\hline Salaattikastike & 5 & 86 & 21 & 0,7 & 2,0 & 0,0 \\
\hline Sekaleipä, vaalea, vehnäjauho, vehnärouhe & 70 & 761 & 182 & 32,4 & 2,9 & 5,9 \\
\hline Kasvirasvalevite, 60 \% rasvaa & 8 & 187 & 45 & 0,0 & 5,0 & 0,0 \\
\hline \multirow[t]{3}{*}{ Rasvaton maito } & 200 & 284 & 68 & 9,8 & 0,2 & 6,2 \\
\hline & & 2549 & 610 & 78,8 & 22,4 & 20,9 \\
\hline & & & & 315,2 & 201,5 & 83,5 \\
\hline \multicolumn{3}{|c|}{ Energian saanti \% hiilihydraateista, rasvasta, proteiinista } & & 51,7 & 33,1 & 13,7 \\
\hline Ohrasuurimopuuro & 250 & 1091 & 259 & 20,9 & 18,2 & 3,4 \\
\hline Mansikka-karpalokiisseli & 200 & 780 & 180 & 46 & 0 & 0 \\
\hline Polar -juustoviipale, $15 \%$ & 20 & 192 & 46 & 0,0 & 3,0 & 4,5 \\
\hline Jääsalaatti, irtolehti & 15 & 7 & 2 & 0,2 & 0,0 & 0,2 \\
\hline Sekaleipä, vaalea, vehnäjauho, vehnärouhe & 60 & 652 & 156 & 27,78 & 2,52 & 5,1 \\
\hline Kasvirasvalevite, 60 \% rasvaa & 6 & 134 & 32 & 0,0 & 3,6 & 0,0 \\
\hline \multirow[t]{3}{*}{ Rasvaton maito } & 200 & 284 & 68 & 9,8 & 0,2 & 6,2 \\
\hline & & 3140 & 743 & 104,6 & 27,7 & 19,8 \\
\hline & & & & 418,5 & 249,3 & 79,2 \\
\hline \multicolumn{3}{|c|}{ Energian saanti \% hiilihydraateista, rasvasta, proteiinista } & & 56,3 & 33,6 & 10,7 \\
\hline Currybroilerikastike & 150 & 581 & 142 & 7,2 & 6,5 & 12,4 \\
\hline Täysjyväriisi (raaka) & 40 & 580 & 137 & 28,1 & 1,2 & 3,4 \\
\hline Valkokaali-kurkkusuikalesalaatti & 40 & 34 & 8 & 1,4 & 0,1 & 0,4 \\
\hline Salaattikastike & 10 & 172 & 41 & 1,3 & 4 & 0 \\
\hline Sekaleipä, vaalea, vehnäjauho, vehnärouhe & 70 & 761 & 182 & 32,4 & 2,9 & 5,9 \\
\hline Kasvirasvalevite, 60 \% rasvaa & 10 & 223 & 53 & 0,02 & 6 & 0,01 \\
\hline \multirow[t]{3}{*}{ Rasvaton maito } & 200 & 284 & 68 & 9,8 & 0,2 & 6,2 \\
\hline & & 2633 & 631 & 80,2 & 21,0 & 28,3 \\
\hline & & & & 320,6 & 188,6 & 113,3 \\
\hline \multicolumn{3}{|c|}{ Energian saanti \% hiilihydraateista, rasvasta, proteiinista } & & 50,8 & 29,9 & 18,0 \\
\hline Currybroilerikastike & 150 & 581 & 142 & 7,2 & 6,5 & 12,4 \\
\hline Täysjyväpasta & 100 & 1400 & 330 & 62 & 2 & 16 \\
\hline Valkokaali-kurkkusuikalesalaatti & 40 & 34 & 8 & 1,4 & 0,1 & 0,4 \\
\hline Salaattikastike & 5 & 86 & 21 & 0,65 & 2 & 0 \\
\hline Sekaleipä, vaalea, vehnäjauho, vehnärouhe & 50 & 544 & 130 & 23,15 & 2,1 & 4,25 \\
\hline Kasvirasvalevite, 60 \% rasvaa & 6 & 134 & 32 & 0,012 & 3,6 & 0,006 \\
\hline \multirow[t]{3}{*}{ Rasvaton maito } & 200 & 284 & 68 & 9,8 & 0,2 & 6,2 \\
\hline & & 3062 & 731 & 104,2 & 16,5 & 39,3 \\
\hline & & & & 416,7 & 148,6 & 157,1 \\
\hline \multicolumn{3}{|c|}{ Energian saanti \% hiilihydraateista, rasvasta, proteiinista } & & 57,0 & 20,3 & 21,5 \\
\hline Taulukko: I & & & & & & \\
\hline
\end{tabular}

\section{Tulokset}

Kouluruokien ilmastovaikutukset on seuraavassa kuvassa 2 esitetty ateriakomponenteittain kilogrammoina ekvivalenttista hiilidioksidia (kg CO2 ekv). Esimerkkikoulun peruslounaiden ilmastovaikutus oli väillä 0,56 ja 1,94 kg CO 2 ekv., keskiarvo 1,162 $\mathrm{CO}_{2}$ ekv.. 


\section{Kouluruokien ilmastovaikutus $\mathrm{kg} \mathrm{CO}$-ekv}

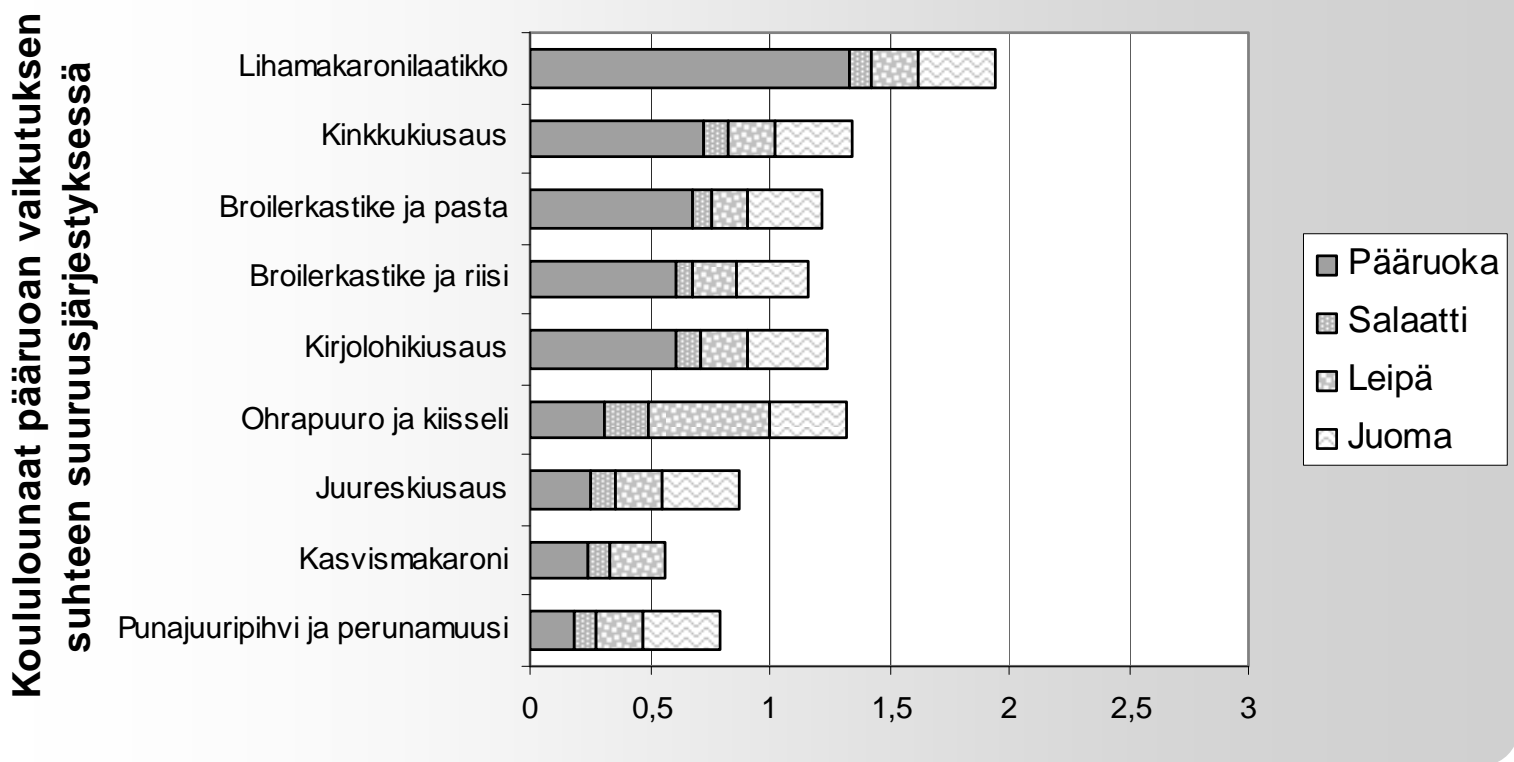

Kuva 2. Kouluruokien ilmastovaikutus ateriakomponenteittain eriteltynä.

Esimerkkikoulun lounaisiin tehtiin salaatin osalta vaihdos, jossa edellä kuvatut sesongin mukaiset salaatit vaihdettiin ympärivuotisessa kasvihuoneessa tuotettuihin tomaatti-kurkkulehtisalaatti - salaatteihin (Kuva 3)

\section{Kouluruokien ilmastovaikutus kg CO2 ekv.}
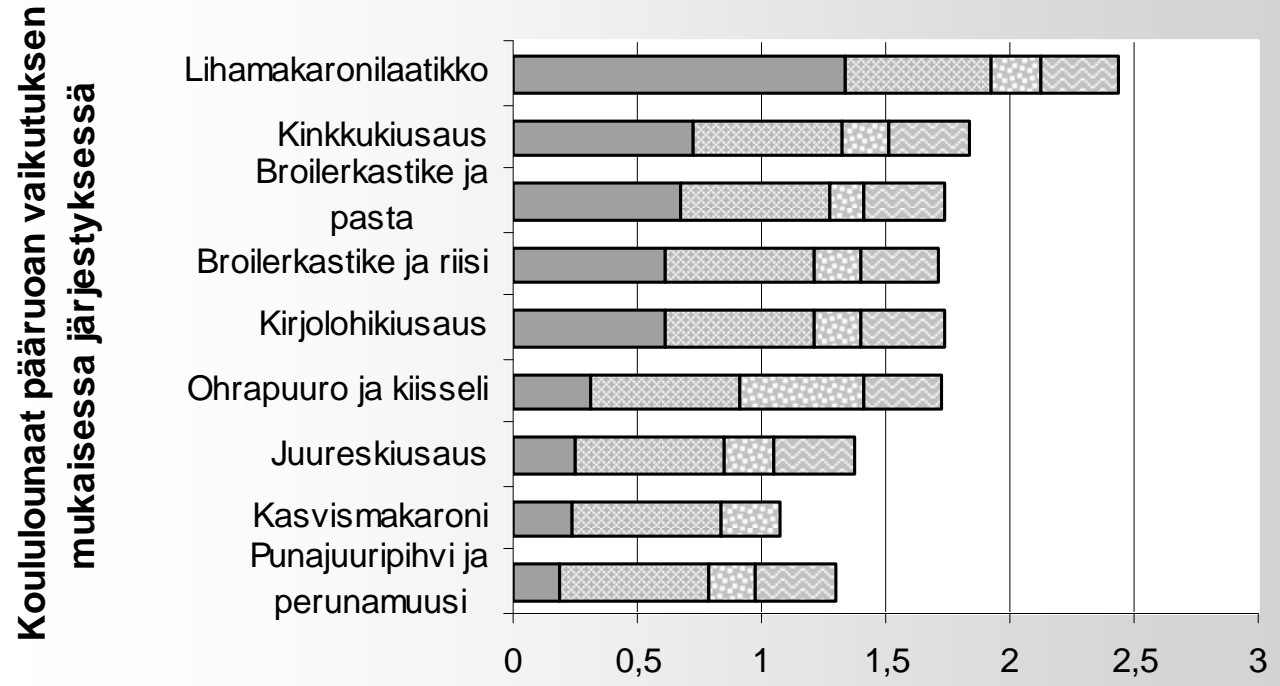

口 Pääruoka

$\square$ Salaatti

$\square$ Leipä

$\square$ Juoma

Kuva 3. Kuvan 1 kouluruokien salaatti vaihdettu sesonkisesta kasvihuonetuotteisiin.

Alkuperäiset esimerkkikoululounaat edustavat varsin hyvin vuodenaikaista sesonkia ja hyvää kylmäsäilyvyyttä hyväksikäyttäviä salaattivaihtoehtoja (vertaa ateriakuvaukset taulukossa 1). Punajuuri ja porkkana edustavat syyssesonkia ja säilyvät hyvin kevättalveen saakka, valkokaali kuuluu samaan ryhmään, kiinankaali on syyskauden tuote, mutta säilyvä. Kurkku saattaa olla ympäristövaikutuksiltaan hyvin vaihteleva tuote. 
Edellä kuvattu salaatin vaihdos aiheuttaa lounaiden ravitsemukselliseen arvoon vain hyvin pienen muutoksen (energiamääränä suurimmillaan noin 15 Kcal). Ympärivuotisessa tuotannossa tuotetun salaatin avulla muunnettujen lounaiden ilmastovaikutus nousi 20-40 \%, välille 1,07 ja 2,44 kg CO $\mathrm{C}_{2}$ ekv, ja annosten keskiarvo oli 1,66 kg CO 2 ekv.

Kuntien ruokapalvelupäälliköille suunnatussa selvityksessä tuli ilmi että kesä- ja syyskauden aikana lähes 90 \%:lla kouluista pääosa (vähintään 3/4 osaa) perunasta, 70 \%:lla kouluista pääosa juureksista, lähes 60 \%:lla kouluista pääosa vihanneksista ja vain 40 \%:lla kouluista vähintään 3/4 osaa marjoista olivat kotimaisia, ja vastaavasti perunan osalta oman maakunnan tuotteet ovat pääsääntöisesti käytössä vain 60 \%:lla kouluista ja oman maakunnan juurekset, vihannekset ja marjat vain 20-30\%lla kouluista. Talvikauden aikana kotimainen tai oman maakunnan peruna säilyttää kohtalaisesti valta-asemansa. Juuresten osalta kotimaisuuden valta-asema putoaa alle puoleen kouluista ja oman maakunnaan juuresten valta-asema noin 20 \%:iin kouluista. Kuitenkin ruokapalvelun ruokalistojen laadinnassa sesonkisuutta on pidetty kolmantena kriteerinä tärkeysjärjestyksessä, jossa edellä ovat hinta ja ravitsemussuositukset. Sesonkisuus näyttää siten käytännössä irtaantuneen lähialuemerkityksestä.

Esimerkkilounaista rehevöittävimmäksi osoittautui kasvatettuun kalaan perustuva lounas (Kuva 4). Muutoin lounaat asettuvat vaikutustensa suhteen suurin piirtein samaan järjestykseen kuin ilmastovaikutusten osalta. Kasvispohjaiset pääruoat sijoittuvat rehevöittävien vaikutustensa osalta kevyimpään ryhmään.

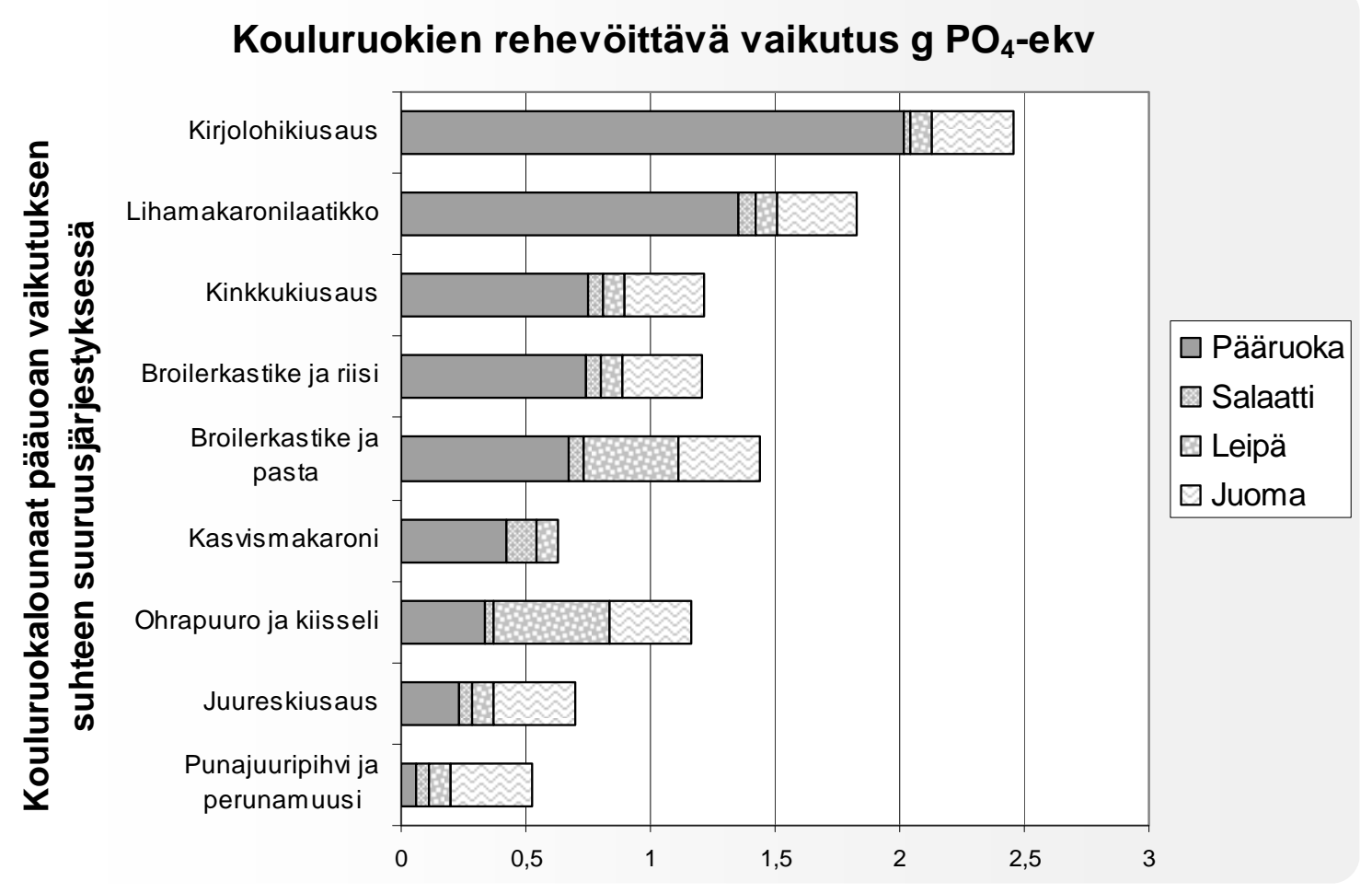

Kuva 4. Koululounasannosten vesistöjä rehevöittävä vaikutus

Rehevöittävyysmittarin arvoina esimerkkilounaiden vaihteluväli on noin puolesta grammasta fosfaattiekvivalenttia noin 2,5 grammaan fosfaattiekvivalenttia ( $\mathrm{g} \mathrm{PO}_{2} \mathrm{ekv}$ ).

Ruoan tuotannon rehevöittävät vaikutukset ovat koko kulutuksen ympäristövaikutusten osana suhteellisesti paljon merkittävämmät kuin ruoan ilmastovaikutukset. Suomalaisen keskimääräisistä ilmastomuutosvaikutuksista ruokaketju muodostaa noin 15 - $18 \%$ mutta keskimääräisistä päivittäisistä rehevöittävistä vaikutuksista ruoan osuus on jopa $90 \%$ (Kuva 5, ota huomioon että lounas on noin kolmannes päivittäisestä ruoan kulutuksesta). Siis suurin osa kansallisista rehevöittävistä vaikutuksistamme liittyy ruokaketjuun. 


\section{Esimerkkilounaiden suhteellinen osuus suomalaisen kuluttajan päivittäisestä rehevöittävästä kokonaiskuormituksesta}

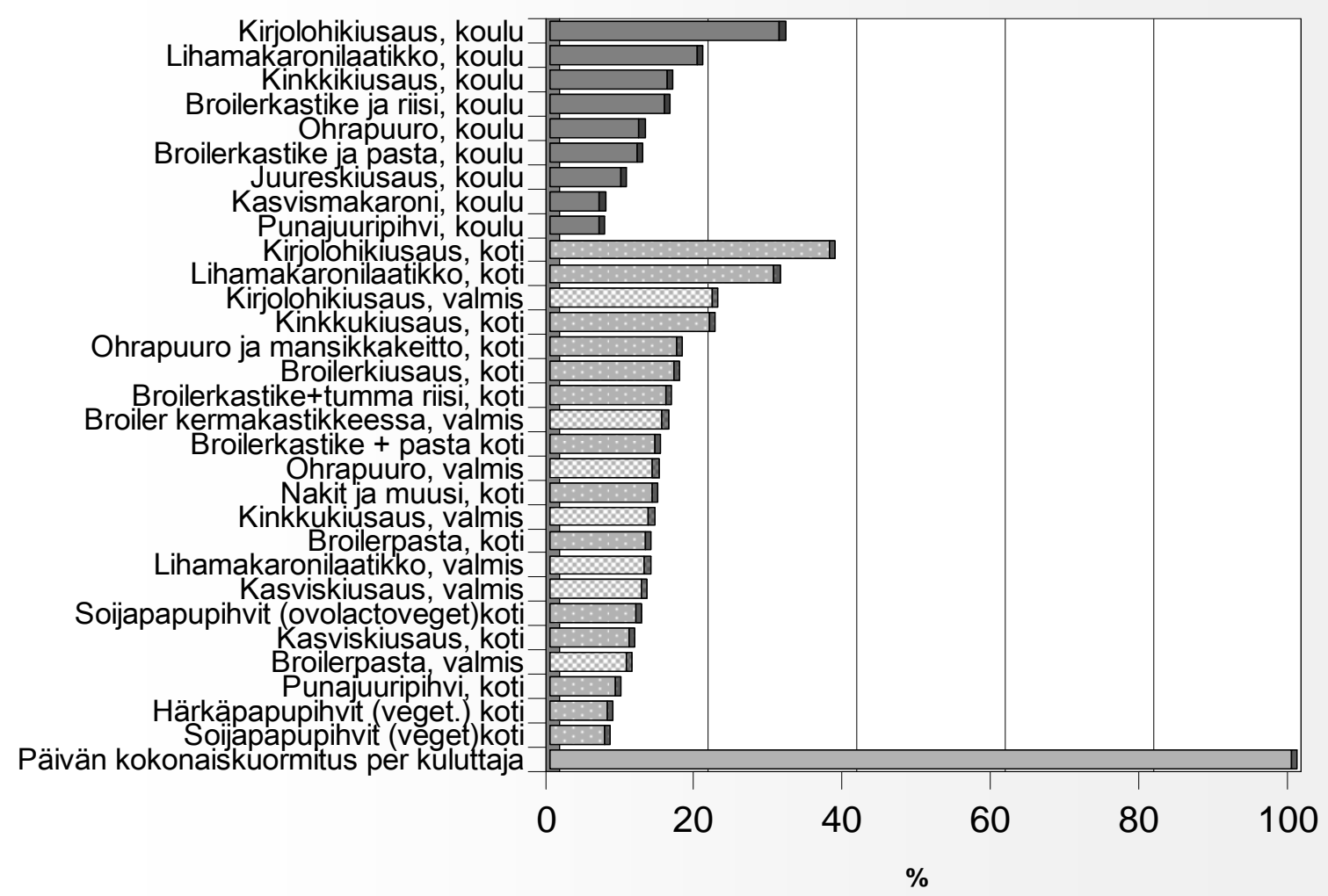

Kuva 5. Koululounaiden rehevöittävä vaikutus verrattuna kotona valmistettuihin (pistekuviolla korostetut) ja valmisruoista koottuihin (ruudutuksella korostetut) lounasannoksiin. Verrranteena suomalaisen keskimääräinen päiväkuormitus Mittatikku- menetelmän mukaisesti, http://www.ymparisto.fi/default.asp?contentid=155916\&lan=fi

Kotimaisia ja ulkomaisia tuotteita verrattaessa kriittinen kohde on riisi, verrattuna vaihtoehtoiseen viljaan. Esimerkkilounaiden joukossa vertailukohteena on pääruokapari broilerikastike ja pasta sekä broilerikastike ja tumma riisi (Kuva 6 a ja b). Kun verrataan näitä kahta ruoka-annosta toisiinsa, viljaraaka-aineen ilmastovaikutukset ovat broilerikastike ja tumma riisi-annoksessa $30 \%$ suuremmat kuin broilerikastike ja pasta-annoksessa. Riisiä on annoksessa $40 \mathrm{~g}$ ja pastaa $100 \mathrm{~g}$. Lisäksi riisiannoksessa on 20 g enemmän leipää, jonka osuus ei kuitenkaan selitä ilmastovaikutusten eroa. Riisin ilmastovaikutus on nimittäin likipitäen $3 \mathrm{~kg} \mathrm{CO}$ ekv/kg riisiä ja vehnällä ilmastovaikutus jää alle $\mathrm{kg} \mathrm{CO} / \mathrm{kg}$ viljaa. Riisiä on hyvin monenlaista, joten ympäristövaikutuksetkin muodostuvat monella eri tapaa. Kuitenkin arvioidaan, että keskimäärin 68 \% ilmastomuutosvaikutuksista aiheutuu maaperän metaani ja dityppioksidipäästöistä (Blengini \& Busto 2009). Riisin epäedullisuus ei siis johdu kuljetuksesta, kuten ulkomaisten tuotteiden osalta helposti kuvitellaan.

Julkisten ruokapalvelutoimijoiden kehittämissuunnitelmissa ympäristökysymykset ovat nousseet jo kohtalaisen korkeaan asemaan hinnan, tuoreuden ja saatavuuden jälkeen. Ympäristökysymys ei kuitenkaan hahmotu vielä ruoan taustatekijänä vaan kierrätyksenä ja ruoanvalmistuksen energian kulutuksena. Edes biojäte tai muista ympäristökysymyksistä ei juuri ollenkaan pidetä asiakkaille (koululaisille) suunnatun tiedotuksen aiheena. Ilman muutosta koululaisten ruoan kautta muodostuva luontosuhde tulee edelleen etääntymään. Yksi muutosmahdollisuus olisi vuosittaisen ruokavalion aidon sesonkisuuden korostaminen, kansainvälistyneiden reseptien sijasta. 


\section{Broilerikastike ja pasta, lounas, koulu -lounasraaka- aineiden alkutuotannon ilmastovaikutukset eriteltyinä kasvihuonekaasujen merkityksen suhteen}

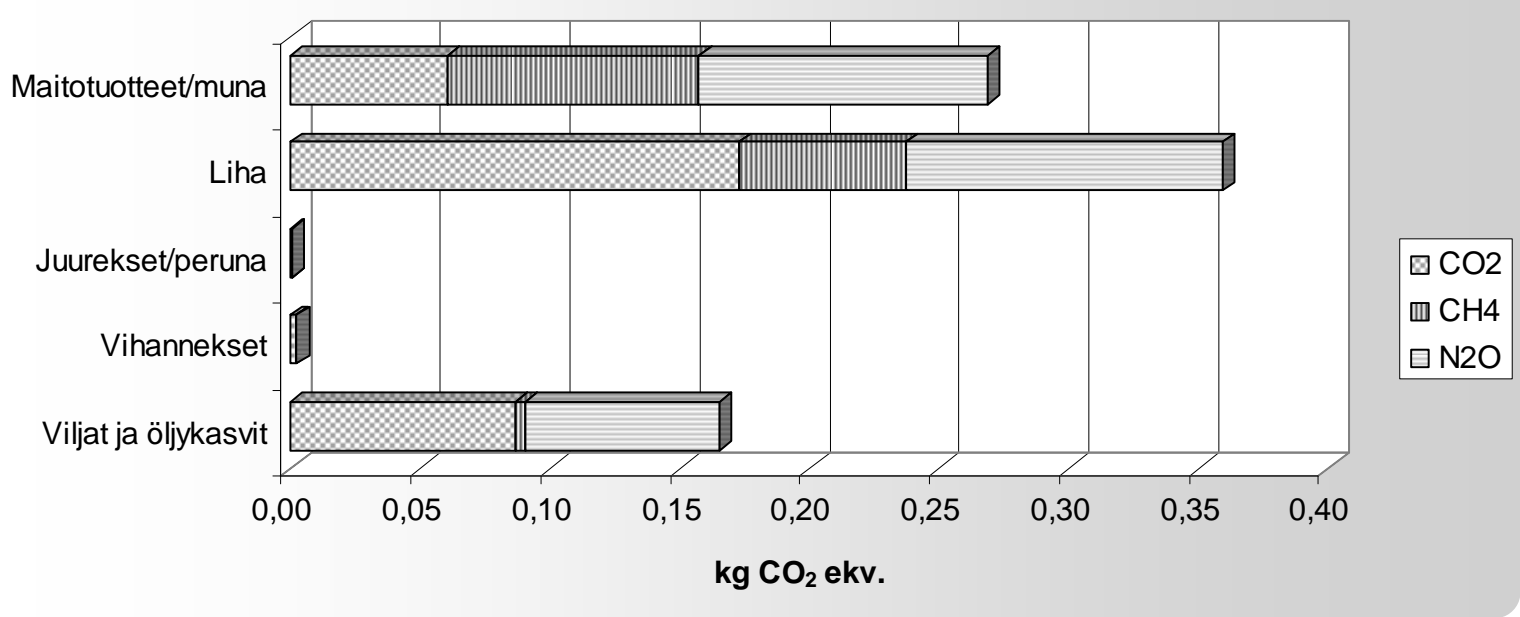

\section{Broilerikastike ja tumma riisi, lounas, koulu -lounasraaka- aineiden alkutuotannon ilmastovaikutukset eriteltyinä kasvihuonekaasujen merkityksen suhteen}

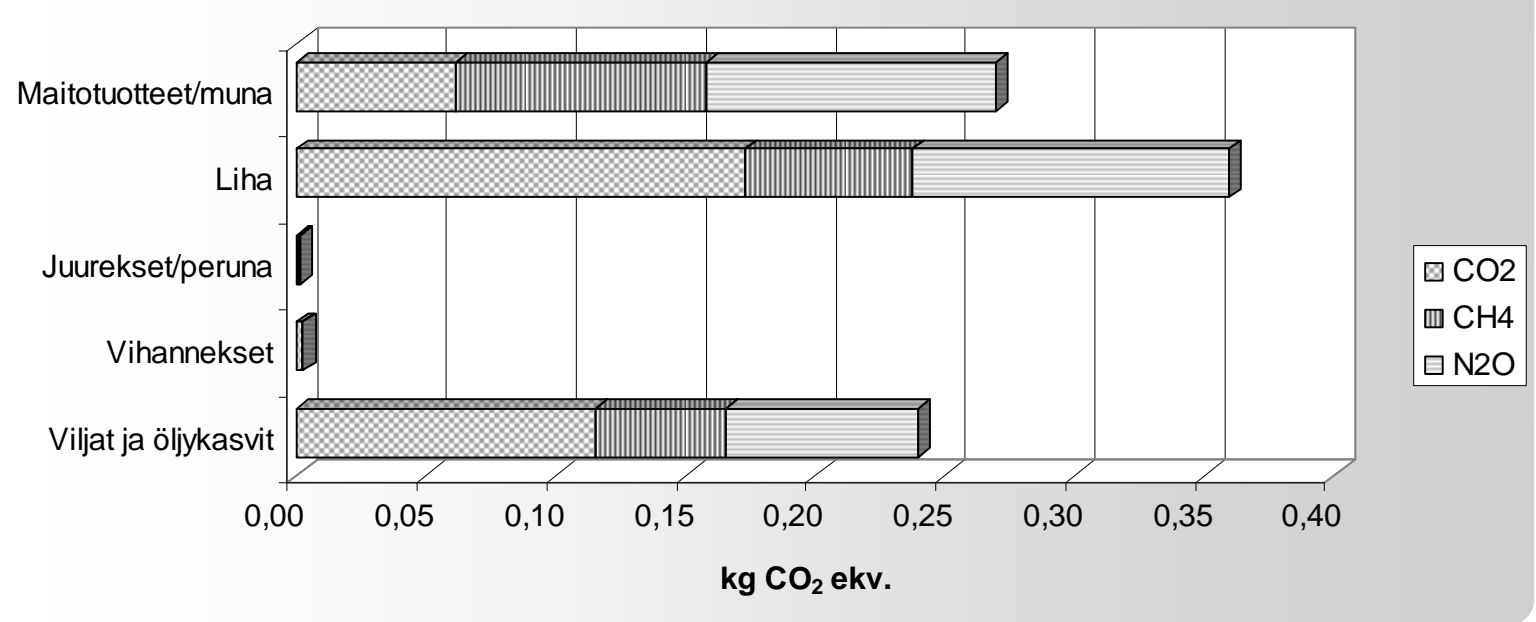

Kuva 6 a ja b. Kuvassa vertailupari broilerikastike ja pasta (ylempi kuva) sekä broilerikastike ja tumma riisi (alempi kuva). Eri raaka-aineiden tuotantoketjun kasvihuonepäästöjen osuus esitetty ilmastovaikutukseltaan yhteismitallistettuina hiilidioksidiekvivalentteina.

\section{Johtopäätökset}

Ruoka-annosten osalta hyvä muistisääntö: keskimääräisten arki-aterioiden ilmastovaikutukset vaihtelevat välillä $0,7 \mathrm{~kg}$ ja $3,5 \mathrm{~kg}$ hiilidioksidiekvivalenttia $\left(\mathrm{kg} \mathrm{CO}_{2} \mathrm{ekv}\right)$; rehevöittävien vaikutusten osalla näemme likipitäen samoja lukuarvoja mutta dimensiona on grammaa fosfaattiekvivalenttia ( $\mathrm{g} \mathrm{PO}_{2} \mathrm{ekv}$ ); ja kasvatettua kalaa lukuun ottamatta ruoat asettuvat vaikutustensa osalta melko hyvin samaan järjestykseen, elinraaka-ainepohjaiset ruoat kuormittavampiin ja kasviraaka-ainepohjaiset vähemmän kuormittaviin; mutta tuotantotavalla on myös merkitystä. Esimerkkilounaiden osalta kannattaa huomata, että ympäristövaikutukset eivät mitenkään seuraile aterioiden ravitsemuksellisia energia määriä 
Tuotantotapa liittyy kärjistyneimmin sesonkisuuteen. Nykyään pääsääntöisesti vain kasvituotteiden osalta voidaan puhua sesonkisuudesta. Aikaisemmin sesonkisuus oli esillä myös eläintuotteiden osalla; suuri osa teurastuksia tehtiin syksyllä, jolloin kasvukautta voitiin käyttää eläinten loppukasvatukseen ja myös lihan säilytys oli talvikauden aikana helpompaa. Edellä kuvatun, sesonkisuuteen liittyvän kasvihuonetuote-esimerkin perusteella pidä tehdä sitä johtopäätöstä, että kasvihuonetuotteita tulisi järjestelmällisesti syrjiä ympäristömyötäistä dieettiä rakennettaessa. Lähinnä kasvihuonetuotannon tulisi ottaa näistä tuloksista vaarin, ja pyrkiä mahdollisimman pian ottamaan uusi teknologia käyttöön, jolloin kasvihuonetuotannon energiatausta saadaan muutettua fossiilisesta uusiutuvaan energiaan ja ympäristövaikutus-tilanne muuttuu täydellisesti.

Jos sesonkisuutta ajatellaan yleisemmältä ja ekologiselta pohjalta, tulisi pitää itsestään selvänä, ettei erilaisten raaka-aineiden parhaita luontaisia tuotantoaikoja tulisi väheksyä. Kaikki varsinaisesta sesongista irtaantuva tuotanto aiheuttaa ylimääräisiä kustannuksia ja ylimääräisiä ympäristövaikutuksia. Varhaisperunan tuotanto kevään ylioppilasjuhliin edellyttää kasvustojen suojaamista, mahdollisia hallanestosadetuksia, siihen liittyy mahdollisia kasvuston paleltumisia ja sen myötä ravinteiden ekotehokasta käyttöä. Maksamme siis ylimääräisen hinnan tuotannon ylimääräisistä ympäristövaikutuksista.

Tulosten mukaan näyttää hyvin ilmeiseltä, että vuodenaikaisia sesonkeja noudatteleva ruokavalio muodostuu ympäristön kannalta edullisimmaksi. Sesonkisuuden tai hyvin säilyvien lähituotteiden asemaa ei voida pitää mitenkään vahvana julkisten ruokapalvelujen hankinnoissa, vaikka toisaalta tuoreutta korostetaan valintakriteerinä ja lähiruokaprojektit nostetaan mielellään esille. Vuodenaikaisuus liittyy vahvasti suomalaiseen ruokakulttuuriin. Se on perinteisesti ollut 'säiden armoilla'. Suomalaisen raaka-ainetuotannon tulisi vahvistaa suomalaisen urbaanin väestön ymmärrystä ruokaraaka-ainetuotannon luonnonresurssiriippuvuudesta eikä pyrkiä kumoamaan sitä. Jotkut urbaanit ympäristöjärjestöt korostavat jo urbaaniviljelyä, jossa tuo luonnonresurssiriippuvuus tulee konkreettisesti esille. Urbaanin viljelyinnostuksen merkitys ruoan saatavuuden kannalta tuskin koskaan on merkittävä, mutta luontokontekstin ymmärtämisen kannalta se on erittäin merkittävä. Tällaisten prosessien arvo tulee nähdä ja ymmärtää myös raaka-ainetuotannon ammattilaisten piirissä.

Hiilihydraattilähteenä nykyään entistä enemmän käytettävän riisin kotimaiset vaihtoehdot ovat vastaavaan tarkoitukseen muotoillut viljatuotteet kuten helmiryynit, joista Raision tuotteen hiilijalanjälki on heti $30 \%$ pienempi kuin riisin (http://www.raisio.com/www/page/2503). Vielä tavanomaisempia riisin korvaajia ovat erilaiset pastatuotteet, joiden hiilijalanjälki on tasolla $110 \mathrm{~g}$ ekvivalenttista $\mathrm{CO}_{2} / \mathrm{kg}$ keitettävää pastaa ja meille kaikkein perinteisimpänä peruna, jonka hiilijalanjälki ilmoitetaan useimmiten tasolle $80 \mathrm{~g}$ ekvivalenttista $\mathrm{CO}_{2} / \mathrm{kg}$ raakaa perunaa

\section{Kirjallisuus}

Blengini G. A. \& Busto M. 2009. The life cycle of rice: LCA of alternative agri-food chain management systems in Vercelli (Italy). Journal of Environmental Management 90 1512-1522.

Risku-Norja H., Kurppa S., Silvennoinen K., Nuoranne A. \& Skinnari J. 2010. Julkiset ruokapalvelut ja ruokakasvatus: arjen käytäntöjen kautta kestävään ruokahuoltoon. MTT Kasvu (painossa). 